\title{
Th- and U-bearing minerals in the SE Mediterranean margin of Spain
}

\author{
1. Laboratorio de Geologia Planetaria, Centro de Astrobiologia (CSIC-INTA) Ctra de Torrejón a Ajalvir, km 4, 28850 Torrejón de Ardoz, \\ Madrid (Spain).e-mail: martinezfrias@mncn.csic.es \\ 2. Departamento de Cristalografía y Mineralogİa, Facultad de Ciencias Geológicas, Universidad Complutense de Madrid, 28040 Madrid \\ (Spain).e-mail: lunar@geo.ucm.es \\ 3. Departamento de Geología, Museo Nacional de Ciencias Naturales, CSIC José Gutierrez Abascal, 2 , 28006 Madrid (Spain), \\ e-mail: monr114@mncn.csic.es
}

\begin{abstract}
This paper presents the first specific study of the Th-and U-bearing minerals, which were recently found in the SE Mediterranean margin of Spain (El Hoyazo area, Almería province). These minerals are REE phosphates (mainly monazite) which occur as amoeboidal-to-elongate inclusions, from around $10 \mu \mathrm{m}$ to $120 \mu \mathrm{m}$, hosted in single garnet crystals from dacite lavas and metamorphic rocks from the El Hoyazo Volcanic Complex. Th and $U$ contents are higher than $1 \mathrm{wt} \%$, with 3.04 to 5.62 wt $\%$ for $\mathrm{ThO}_{2}$, and 0.7 to $1.75 \mathrm{wt} \%$ for $\mathrm{UO}_{2}$. Both elements are also found in xenotime $\left(\mathrm{ThO}_{2}: 0.24, \mathrm{UO}_{2}\right.$ : $0.27 \mathrm{wt} \%)$. Given that the erosion of the volcanic source rocks has generated a "placer-type" deposit of monazite sands and that garnets (main carriers of monazite) are being commercialised, an environmental monitoring and management plan should be urgently executed in the area.
\end{abstract}

\section{Introduction}

It is well known that uranium and thorium are responsible for the majority of naturally occurring radioactive materials. Their decay produces radium, radon, and several isotopes of polonium, lead, and bismuth. Perhaps the best known is radon, which is a gas. The concentration of uranium in the Earth's upper crust is about $3 \mathrm{ppm}$. Naturally occurring uranium nominally contains $99.28305 \%$ by weight ${ }^{238} \mathrm{U}, 0.7110 \%{ }^{235} \mathrm{U}$, and $0.0054 \%{ }^{234} \mathrm{U}$. Studies show that the percentage weight of ${ }^{235} \mathrm{U}$ in natural uranium varies by as much as $0.1 \%$, depending on the source (Lide, 2003). Despite its relative scarcity, uranium occurs in numerous minerals such as pitchblende, uraninite, carnotite, autunite, uranophane, and tobernite. It is also found in phosphate rock, lignite and monazite sands. Thorium is about three times as abundant as uranium (12 ppm). ${ }^{232} \mathrm{Th}$ occurs naturally and has a half-life of $1.4 \times 10^{10}$ years. Thorium is a trace element commonly associated with clays and heavy minerals. It occurs in thorite and in thorianite and is specially recovered from the mineral monazite, which contains 3 to $9 \% \mathrm{ThO}_{2}$ along with rareearth elements (US Department of Energy, 1999). Approximately 200 minerals contain uranium or thorium, which exist in different geological settings and materials in the world.

Several works tackle the presence and concentration mechanisms of radiogenic elements in Spain: a) water and sediments (Herranz, et al. 1999, Andreo and Carrasco, 1999, Pujol and SanchezCabeza, 2000, González-Labajo, 2001, Pelegrina and Martínez-
Aguirre, 2001); b) natural radionuclides in marsh areas (MartinezAguirre and Perianez, 1999); c) granitic rocks (Reyes et al. 1998); d) estuarine systems (San Miguel et al. 2001); e) coals (Alvarez and Rivero, 1998); f) radioactivity in aerosols as a function of meteorological variables (García-Talavera, 2001), and phosphate ores (Martinez-Aguirre and García-Leon, 1997), among others. Specific works on the S and SE (Mediterranean margin) of Spain are scarce and are focussed on regional hydrogeochemical distributions (Dueñas et al. 1998), the prediction of radionuclide transport in the Mediterranean sea chain (Maderich, 1999), and some studies regarding the manmade radioactivity of some areas (e.g. Palomares area, Almeria province).

This work presents the first specific study of Th and U bearing minerals which were recently found in the SE Mediterranean margin of Spain (El Hoyazo, Almería province) (Muñoz-Espadas et al. 2000). They are REE phosphates which occur as amoeboidal-toelongated inclusions, from around $10 \mathrm{~m}$ to $120 \mu \mathrm{m}$, hosted in single garnet crystals from dacite lavas and metamorphic rocks (Figure 1) which form part of a geologically well- defined volcanic outcrop: El Hoyazo Volcanic Complex. The Complex consists of an erosional remnant of a peraluminous volcanic-subvolcanic dacite dome (a pipe and surrounding block lava) of the high-K calc-alkaline type, which forms a shallow hill. The erosion of this outcrop has generated a terrigenous deposit (monazite-rich sands) formed by the destruction of the volcanic dome. Here we describe the characteristics of the geological and petrological framework in which the minerals that host the uranium and thorium occur, as well as their paragenesis, textures and chemical features. The possible environmental implications of both the volcanics and the monazite-rich sands are also stressed.

Given that the erosion of the volcanic source outcrop has generated a "placer-type" deposit of monazite sands (Muñoz-Espadas et al. 2000) and that garnets (main carriers of the monazite) are being sporadically commercialised, an environmental monitoring and management plan should be urgently executed in the area.

\section{Geological setting}

The El Hoyazo Volcanic Complex (EHC) forms part of the Neogene volcanic province of the Mediterranean margin of Spain. This province is located to the east of the Betic Cordillera and extends from Cabo de Gata (Almería province) to Cartagena (Murcia province). The magmas generated in this region include the following rock series: calc-alkaline, K-rich calc-alkaline, shoshonitic, ultrapotassic and alkaline basaltic (Lopez Ruiz and Rodriguez Badiola, 1980). Radiometric dating indicates two episodes of magmatic activity (Bellon, Bordet and Montenat, 1983). The first began in the Late-Burdigalian/Early-Langhian with the generation of CA rocks, continued with simultaneous extrusion of calc-alkaline, K-rich calcalkaline and shoshonitic rocks, and ended in the Messinian with 


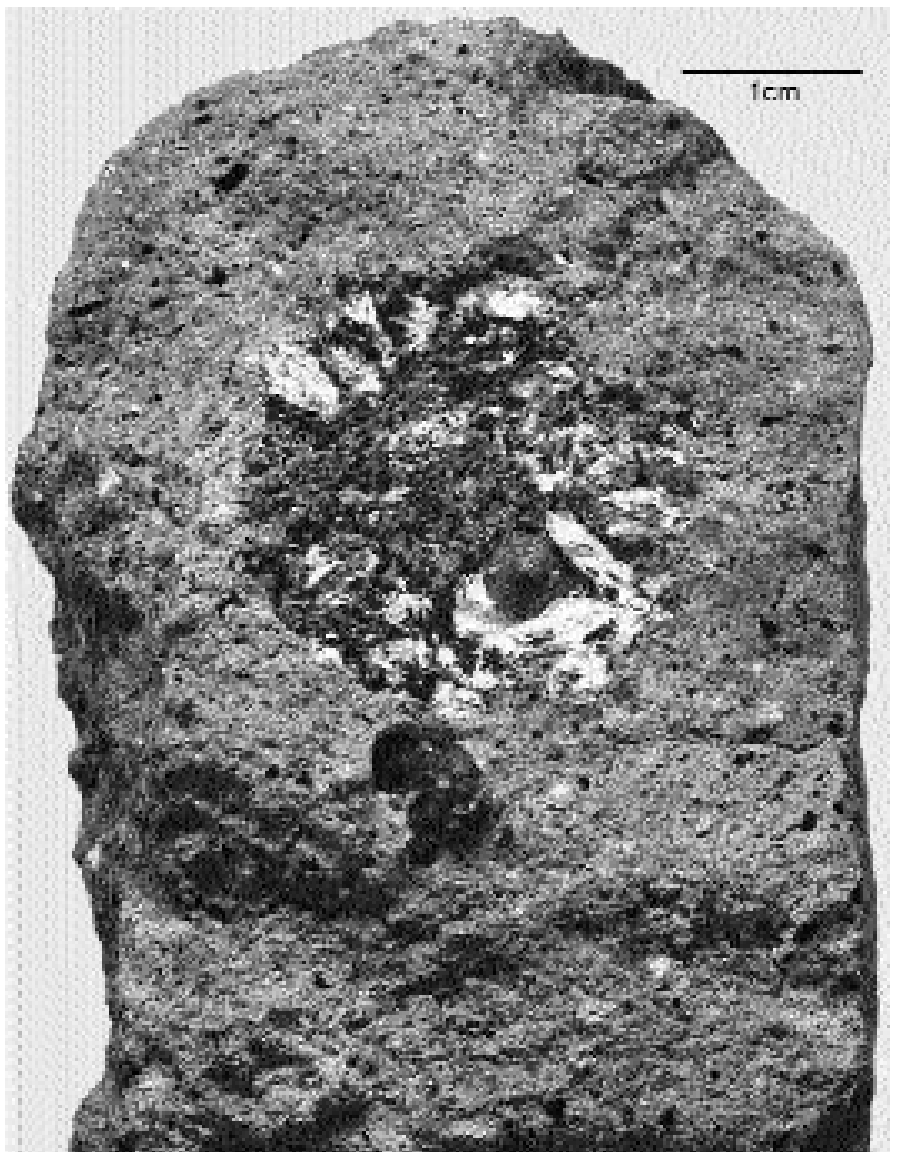

Figure 1 Typical metamorphic xenolith that are hosted in the volcanics. Note that the single crystals of garnet occur in the xenolith and in the dacite.

emplacement of ultrapotassic rocks. The second episode began $2 \mathrm{Ma}$ later, with generation of the alkaline basalts. The K-rich calc-alkaline and shoshonitic rocks occur as domes, lacolites and dikes, and the main volcanic areas where they are found are: El Hoyazo and Vera (Almería province), and Mazarrón and Mar Menor (Murcia province). In general terms, the calc-alkaline and shoshonitic rocks are characterized by abundant metamorphic and igneous xenoliths as well as other inclusions of isolated crystals of garnet and cordierite. This richness of rock and mineral inclusions is more emphasised in El Hoyazo than elsewhere (Zeck, 1968).

The EHC is an extremely garnet-rich volcanic-subvolcanic dacite dome made up of $\mathrm{K}$-andesite and dacite, which covers a circular area of approximately $0.7 \mathrm{~km}^{2}$. It is situated between two sedimentary episodes and the central cone has been eroded. Although other garnet-rich zones exist in Spain (Sierra Nevada, Granada; El Cabril, Hornachuelos, Córdoba; Sierra Capelada, La Coruña, among others), El Hoyazo is unique being the only place where garnet can be found in such a large quantities and diversity. The garnet occurs (1) as isolated idiomorphous crystals (2 to $10 \mathrm{~mm}$ in size) in the volcanics; (2) as principal components of metamorphic xenoliths (crystals of up to $1.5 \mathrm{~cm}$ in size), and (3) as debris formed by the erosion of the volcanic dome. This is extremely important as garnet is the mineral where inclusions of monazite and xenotime occur. In addition, El Hoyazo is, following Zeck (1968), where the first described cordierite was found (this mineral occurs in clear association with the garnet). Detailed descriptions of the petrology and geochemistry of the volcanics from the EHC can be found in Zeck $(1968,1970)$, López Ruiz et al. (1977), Molin (1980), Munksgaard (1984, 1985), Zeck (1992), Benito (1993), Cesare et al. (1997), Benito et al. (1999), Lunar et al. (1999) and Muñoz-Espadas et al. (2000).

\section{U-Th-bearing monazite. Source rocks (metamorphic xenoliths) and main characteristics}

The REE phosphate, monazite, is an important mineral comprising three compositional varieties, Ce-monazite: $(\mathrm{Ce}, \mathrm{La}, \mathrm{Nd}, \mathrm{Th}) \mathrm{PO}_{4}, \mathrm{La}-$ monazite: (La,Ce,Nd)PO ${ }_{4}$, and Nd-monazite: (Nd, Ce, $\mathrm{La}, \mathrm{Pr}, \mathrm{Sm}$, Gd) $\mathrm{PO}_{4}$. Monazite has different mineralogical and geological applications: as a repository for rare earths (mainly $\mathrm{Ce}, \mathrm{La}$ and $\mathrm{Gd}$ ) and $\mathrm{Th}$ and $\mathrm{U}$ in the continental crust; for understanding of the processes involving fluid-rock interactions; for petrogenetic and geochemical studies concerning both the grade of metamorphic events and determination of crustal protolith composition; for $\mathrm{U}-\mathrm{Th}-\mathrm{Pb}$ geochronology, etc. In SE Spain, works about monazite are very scarce (Cesare et al., 2003), but they cover wide petrologic, geochemical, and geochronological aims in other areas of the Iberian Peninsula (mainly Central and NW Spain) (Bea et al. 1994, Casillas et al. 1995, Zalduegui et al. 1996, Bea, 1996).

The detection of U-Th bearing monazite in the EHC was the result of a detailed sampling of metamorphic rock and single crystal (garnet, cordierite and quartz) inclusions. As indicated above, monazite grains were only found as $\mu \mathrm{m}$-sized inclusions hosted in both garnet crystals and the matrix of the metamorphic xenoliths in the volcanics (Figure 1). The highest quantity of inclusions was found in xenoliths from the north and south zones of the volcanic dome outcrop. These metamorphic xenoliths broadly represent $10-15 \mathrm{vol} \%$ of the EHC dacite, and are made up of both Al-rich restite xenoliths and monocrysts derived therefrom. The rock fragments consist of: 1) almandine-biotite-sillimanite-plagioclase ( \pm cordierite) rock with a well-developed metamorphic foliation, and without quartz or $\mathrm{K}$ feldspar; 2) spinel-cordierite hornfels, and 3) cordierite-quartz rock without plagioclase or K-feldspar. Approximately $1 \mathrm{vol} \%$ of the dacitic rock is made up of $2-10 \mathrm{~mm}$ ruby-red euhedral to subhedral garnet crystals. They do not present any reaction or precipitation products on the crystal edges, and closely resemble the crystals found in Al-rich restite xenoliths in habit, size, colour, inclusions (quartz, biotite, fibrolite), refringence and chemical composition and zoning. Other monocrystal restite xenoliths are corroded quartz (up to $10 \mathrm{~cm}$; average size $\sim 2 \mathrm{~cm})$, anhedral cordierite $(0.5-10 \mathrm{~mm})$, graphite (up to $200 \mu \mathrm{m}$ ), anhedral andesine (100-300 $\mu \mathrm{m}$ ), dark lilac or green spinel hercinite $(50-300 \mu \mathrm{m})$ and usually anhedral zircon (around $50 \mu \mathrm{m}$ ).

Geochemically, the xenoliths display (Table 1) low content of $\mathrm{SiO}_{2}(38.35-50.35 \%)$ but high $\mathrm{Al}_{2} \mathrm{O}_{3}(26.11-36.38 \%), \mathrm{Fe}_{2} \mathrm{O}_{3}, \mathrm{MgO}$ $+\mathrm{TiO}_{2}\left(\mathrm{Fe}_{2} \mathrm{O}_{3}+\mathrm{MgO}+\mathrm{TiO}_{2}:\right.$ 9.06-21.28\%). The geochemical composition of the other major elements varies according to the mineralogy. The compatible trace elements, $\mathrm{Sc}, \mathrm{V}, \mathrm{Cr}, \mathrm{Co}$ and $\mathrm{Ni}$, show higher geochemical values than those from their host volcanics. Some incompatible elements (i.e. $\mathrm{Zr}(226-474)$ and $\mathrm{Nb}$ (20-32) are also higher. The metamorphic xenoliths (source rocks of the U-Th bearing monazite) present almost identical contents of $\mathrm{Rb}$ (113-176), Ba (486-1264 ppm), La (43-58), Ce (84-122), and Pb (11-53 ppm). The concentrations of Sr (52-545) and Th (11-19) are slightly lower (Benito, 1993). Concerning the isotope composition, the xenoliths display ${ }^{87} \mathrm{Sr} /{ }^{86} \mathrm{Sr}$ ratios of between 0.7153 and 0.7303 and $\delta^{18} \mathrm{O}$ values ranging from +9.7 and $+16.2 \%$ o, (Munksgaard, 1984, López Ruiz and Wasserman, 1991, Benito, 1993). Given that, as previously defined, the U-Th bearing monazite has only been found as inclusions in garnets and matrix from the metamorphic xenoliths, its existence could be important regarding the controversy about the origin of the EHC garnet crystals: either by direct crystallization from dacitic melts, or by derivation as restitic monocrysts from the metamorphic xenoliths (Zeck, 1968, 1970, López Ruiz et al. 1977, Molin, 1980; Munksgaard, 1985, Martinez-Frias et al. 1999). 
Table 1 Chemical analyses of major d trace elements from selected samples of almandine-biotite-fibrolite-plagioclase xenoliths (El Hoyazo-garnet rich volcanic Complex).

\begin{tabular}{|c|c|c|c|c|}
\hline & GAT-55 & GAT-38 & GAT-49 & GAT-53 \\
\hline \multicolumn{5}{|c|}{ Major elements, wt $\%$} \\
\hline $\mathrm{SiO}_{2}$ & 38.35 & 40.65 & 42.71 & 45.72 \\
\hline $\mathrm{TiO}_{2}$ & 1.80 & 1.33 & 1.71 & 1.48 \\
\hline $\mathrm{Al}_{2} \mathrm{O}_{3}$ & 36.38 & 34.62 & 32.08 & 28.18 \\
\hline $\mathrm{Fe}_{2} \mathrm{O}_{3}$ & 9.79 & 10.71 & 12.44 & 9.69 \\
\hline $\mathrm{MnO}$ & 0.02 & 0.15 & 0.07 & 0.07 \\
\hline $\mathrm{MgO}$ & 2.71 & 2.34 & 3.64 & 2.30 \\
\hline $\mathrm{CaO}$ & 0.94 & 0.78 & 0.45 & 1.34 \\
\hline $\mathrm{Na}_{2} \mathrm{O}$ & 0.16 & 0.35 & 0.32 & 1.24 \\
\hline $\mathrm{K}_{2} \mathrm{O}$ & 2.72 & 2.78 & 2.95 & 4.27 \\
\hline $\mathrm{P}_{2} \mathrm{O}_{5}$ & 0.10 & 0.12 & 0.21 & 0.17 \\
\hline L.O.I. & 6.63 & 5.46 & 3.15 & 3.43 \\
\hline Total & 99.60 & 99.29 & 99.73 & 97.89 \\
\hline \multicolumn{5}{|c|}{ Trace elements, ppm } \\
\hline $\mathrm{Sc}$ & 20 & 29 & 18 & 19 \\
\hline $\mathrm{Rb}$ & 137 & 136 & 144 & 171 \\
\hline $\mathrm{Sr}$ & 134 & 129 & 52 & 545 \\
\hline $\mathrm{Y}$ & 26 & 71 & 39 & 27 \\
\hline $\mathrm{Zr}$ & 298 & 236 & 285 & 226 \\
\hline $\mathrm{Nb}$ & 32 & 20 & 27 & 27 \\
\hline $\mathrm{Ba}$ & 663 & 951 & 486 & 1264 \\
\hline $\mathrm{La}$ & 47 & 50 & 58 & 48 \\
\hline $\mathrm{Ce}$ & 90 & 93 & 122 & 86 \\
\hline $\mathrm{Pb}$ & 24 & 22 & 24 & 53 \\
\hline
\end{tabular}

\section{Textural and crystal-chemical characteristics}

The U-Th bearing monazite was firstly cited by Muñoz-Espadas (2002) and Cesare et al. (2003). It is the most abundant REE mineral of El Hoyazo. It occurs as tiny, anhedral (mainly amoeboidal) to subhedral elongated inclusions (Figure 2) in both the garnet monocrysts and matrix of the metamorphic xenoliths, with a size ranging from around $10 \mu \mathrm{m}$ to $120 \mu \mathrm{m}$. Monazite's crystal-chemical characteristics were determined on the basis of a large data set of electron microprobe analyses (Jeol Superprobe JXA-8900M), bulk and channel-selected (TAP, PETJ, LIF, PETH) X-ray spectra search and

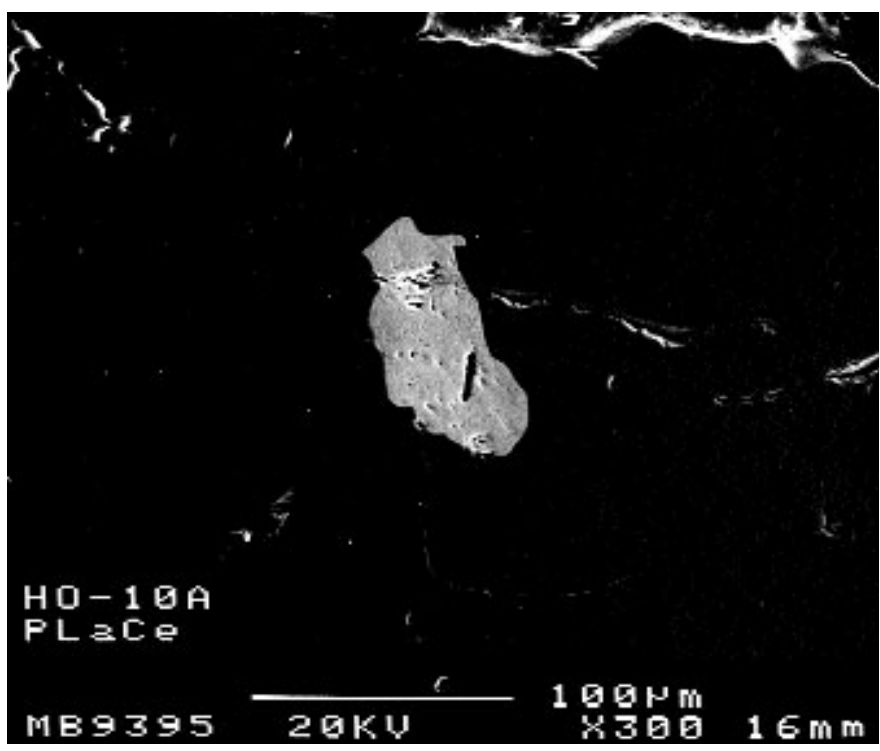

Figure 2 Tiny irregular inclusion of monazite hosted in a garnet crystal from the metamorphic xenoliths. identification routines, along with further SEM studies (JSM-100), including both semi-quantitative analyses and detailed textural observations. Selected electron microprobe analyses of monazite are shown in Table 2. In broad terms they indicate that the type of host crystals/grains, crystal size, degree of idiomorphism and other textural differences are not represented by significant chemical variations. No textural or chemical zoning was detected in different inclusions.

Table 2 Selected electron microprobe analyses of monazites from the metamorphic enclaves (El Hoyazo-garnet rich volcanic Complex). G43B2, G43B4, G10A2, G10A1, G10A9: monazite inclusions in garnet syngle crystals. M10A5 and M10A10: monazite inclusions disseminated in the intergranular matrix.

G43B2 G43B4 G10A2 G10A1 M10A5 G10A9 M10A10

\begin{tabular}{lrrrrrrr}
\hline $\mathrm{SiO}_{2}$ & 0.04 & 0.03 & 0.54 & 0.28 & 0.19 & 0.12 & 0.25 \\
$\mathrm{CaO}$ & 0.14 & 0.13 & 0.11 & 0.16 & 0.17 & 0.15 & 0.17 \\
$\mathrm{P}_{2} \mathrm{O}_{5}$ & 29.40 & 30.41 & 30.32 & 30.14 & 29.82 & 30.05 & 29.18 \\
$\mathrm{Y}_{2} \mathrm{O}$ & 31.17 & 2.30 & 1.81 & 1.96 & 2.32 & 2.09 & 0.95 \\
$\mathrm{Sc}_{2} \mathrm{O}_{3}$ & - & - & - & - & - & - & - \\
$\mathrm{La}_{2} \mathrm{O}_{3}$ & 14.12 & 13.70 & 13.90 & 13.15 & 12.75 & 13.57 & 13.79 \\
$\mathrm{Ce}_{2} \mathrm{O}_{3}$ & 32.37 & 31.87 & 32.24 & 30.70 & 30.01 & 31.95 & 31.85 \\
$\mathrm{Pr}_{2} \mathrm{O}_{3}$ & 0.76 & 0.74 & 0.87 & 0.88 & 0.84 & 0.74 & 0.97 \\
$\mathrm{Nd}_{2} \mathrm{O}_{3}$ & 11.96 & 11.62 & 11.74 & 11.17 & 11.42 & 11.74 & 11.69 \\
$\mathrm{Sm}_{2} \mathrm{O}_{3}$ & 2.27 & 2.03 & 1.88 & 2.06 & 1.96 & 1.87 & 2.24 \\
$\mathrm{Eu}_{2} \mathrm{O}_{3}$ & 0.25 & 0.35 & 0.40 & 0.43 & 0.41 & 0.19 & 0.33 \\
$\mathrm{Gd}_{2} \mathrm{O}_{3}$ & 1.80 & 1.61 & 1.49 & 1.79 & 1.86 & 1.58 & 1.47 \\
$\mathrm{~Tb}_{2} \mathrm{O}_{3}$ & 0.08 & - & - & 0.16 & - & 0.07 & 0.13 \\
$\mathrm{Dy}_{2} \mathrm{O}_{3}$ & 0.55 & 0.67 & 0.64 & 0.58 & 0.63 & 0.64 & 0.34 \\
$\mathrm{Ho}_{2} \mathrm{O}_{3}$ & - & - & - & - & 0.04 & - & - \\
$\mathrm{Er}_{2} \mathrm{O}_{3}$ & 0.22 & 0.45 & 0.35 & 0.43 & 0.39 & 0.40 & 0.11 \\
$\mathrm{Tm}_{2} \mathrm{O}_{3}$ & 0.06 & 0.03 & 0.16 & 0.10 & 0.10 & 0.07 & 0.11 \\
$\mathrm{Yb}_{2} \mathrm{O}_{3}$ & 0.07 & 0.17 & 0.05 & 0.05 & 0.09 & 0.21 & 0.01 \\
$\mathrm{Lu}_{2} \mathrm{O}_{3}$ & 0.13 & 0.14 & 0.03 & 0.02 & 0.11 & 0.06 & 0.06 \\
$\mathrm{ThO}_{2}$ & 3.98 & 3.52 & 3.30 & 5.35 & 5.62 & 3.88 & 5.18 \\
$\mathrm{UO}_{2}$ & 0.80 & 1.03 & 0.71 & 1.36 & 1.75 & 0.93 & 1.20 \\
$\mathrm{ZrO}_{2}$ & 0.04 & - & - & 0.01 & - & - & - \\
$\mathrm{Total}^{2}$ & 100.21 & 100.80 & 00.54 & 100.78 & 100.44 & 100.35 & 100.0 \\
\hline
\end{tabular}

The major anion group $\mathrm{P}_{2} \mathrm{O}_{5}$ is around $30 \mathrm{wt} \%$ (29.03-30.41), and $\mathrm{SiO}_{2}$ values are always below 0.6 wt \% . Among LREE, $\mathrm{Ce}_{2} \mathrm{O}_{3}$ is the most abundant (up to $32.5 \mathrm{wt} \%$ ), followed by $\mathrm{La}_{2} \mathrm{O}_{3}(13.02-$ 14.12), $\mathrm{Nd}_{2} \mathrm{O}_{3}$ (11.17-11.96), $\mathrm{Sm}_{2} \mathrm{O}_{3}$ (1.80-2.27), and $\mathrm{Pr}_{2} \mathrm{O}_{3}$ (0.70-0.97). Among the HREE, $\mathrm{Gd}_{2} \mathrm{O}_{3}$ is the only one with more than 1 wt \% (up to 1.86 wt \%); $\mathrm{Dy}_{2} \mathrm{O}_{3}$ and $\mathrm{Er}_{2} \mathrm{O}_{3}$ show values of around $0.5 \mathrm{wt} \%$, whilst the others display even less than this amount. Yttrium (similar in ionic radius as the HREE, between Dy and $\mathrm{Ho}$ ) is between 0.9 and $2.32 \mathrm{wt} \% \mathrm{Y}_{2} \mathrm{O}_{3}$. All monazite inclusions show a similar descendent trend, and a pronounced negative anomaly in $\mathrm{Yb}$ (Figure 3), which is similar to that found by Zhang and Nozaki (1998) related with seaweed samples. Other non-REE were also detected forming part of the monazite composition, although only Th and $\mathrm{U}$ display contents higher than $1 \mathrm{wt} \%$. Th values range between 3.04 and $5.62 \mathrm{wt} \%$ of $\mathrm{ThO}_{2}$ and $\mathrm{U}\left(\mathrm{UO}_{2}\right)$ ranges from 0.7 to $1.75 \mathrm{wt} \%$. $\mathrm{Zr}$ values are always below the detection limit $(<0.05$ wt $\%$ of $\mathrm{ZrO}_{2}$ ). A good positive correlation is observed between Th and $\mathrm{U}$, and $\mathrm{Y}$ and Er respectively.

To compare these contents with those obtained from the EHC volcanics and metamorphic xenoliths, it is important to take into account that the lavas show the following REE values: La: $52.1 \mathrm{ppm}$, Ce: 104 ppm, Nd: 45.9 ppm, Sm: 7.92, Eu ppm: 1.73, Tb ppm: 0.89, Yb: $1.78 \mathrm{ppm}, \mathrm{Lu}: 0.30 \mathrm{ppm}$. Y ranges between 24 and $41 \mathrm{ppm}$, and Th and U are always below $26 \mathrm{ppm}$ and $8.82 \mathrm{ppm}$, respectively. Finally, the only existent analyses of these trace elements in the metamorphic xenoliths comprise Y (20-71 ppm), Zr (226-474 ppm), La (43-58 ppm), Ce (84-122 ppm) and Th (11-19 ppm). 


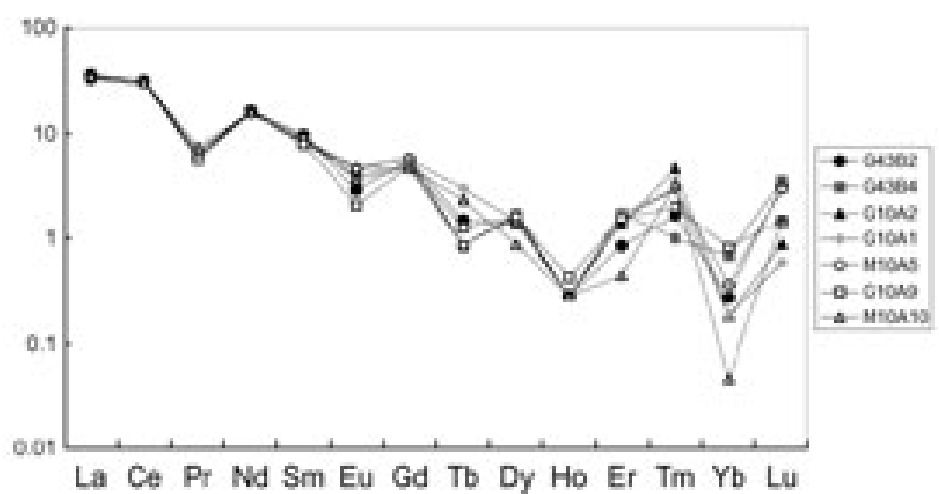

Figure 3 Chondrite-normalized REE distribution plot of monazites from the metamorphic enclaves. G43B2, G43B4, G10A2, G10A1, G10A9: monazite inclusions in garnet single crystals. M10A5 and M10A10: monazite inclusions disseminated in the intergranular matrix.

Besides these chemical features, the $\mathrm{Sm}_{2} \mathrm{O}_{3}$ vs. $\mathrm{La}_{2} \mathrm{O}_{3}$ and $\mathrm{Y}_{2} \mathrm{O}_{3}$ vs. $\sum$ HREE values obtained in the EHC monazites also reflect the high-grade metamorphism undergone by the metamorphic source rocks, which is corroborated by the petrological and geochemical characteristics of the xenoliths (Zeck, 1968).

\section{Other REE (U, Th)-bearing minerals}

Although monazite is the most widespread REE phase in the EHC, other accessory REE (U, Th)-bearing minerals were also found: zircon (Figure 4) which had already been identified by Zeck (1968) and recently was studied in detail by Zeck and Whitehouse (2002), and Cesare et al. (2003) even reaching a crystal size of up to $0.3 \mathrm{~mm}$, and xenotime (Figure 5), cited here for the first time (although only one well-faced inclusion, of around $55 \mu \mathrm{m}$, was found in all the samples studied). The chemical analyses of these two minerals indicate they match the experimental formulas well. In the zircon, almost all the REE, $\mathrm{U}$ and Th are below the detection limit: $0.1 \mathrm{wt} \%$ ); only Gd, Er and $\mathrm{Yb}$ display values which can reach $0.3 \mathrm{wt} \%$. The analysis of the only xenotime found in the EHC (a more in-detail search for xenotime inclusions is currently in progress), gives the following chemical composition: $\mathrm{SiO}_{2}: 1.04, \mathrm{CaO}: 0.05, \mathrm{P}_{2} \mathrm{O}_{5}: 35.36, \mathrm{Y}_{2} \mathrm{O}_{3}: 43.30$, $\mathrm{ThO}_{2}: 0.24, \mathrm{UO}_{2}: 0.27, \mathrm{Gd}_{2} \mathrm{O}_{3}: 5.34, \mathrm{Dy}_{2} \mathrm{O}_{3}: 5.89, \mathrm{Er}_{2} \mathrm{O}_{3}: 4.19$,

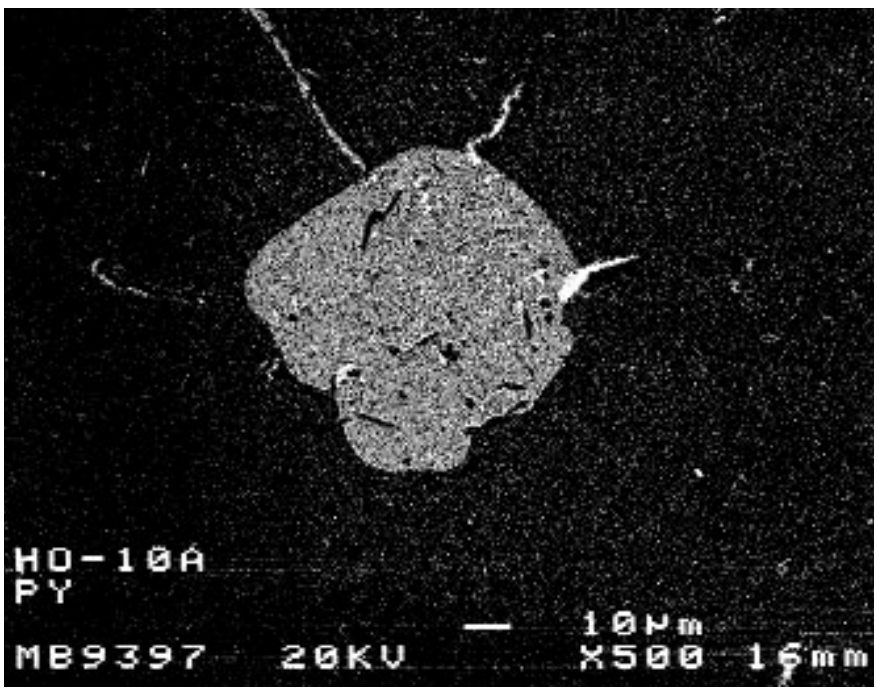

Figure 4 Well-faced inclusion of xenotime. It is the only crystal which was found in the area.
$\mathrm{Yb}_{2} \mathrm{O}_{3}: 4.33$. All other rare earths are below the detection limit (around $0.01 \mathrm{wt} \%$ ).

\section{Conclusion}

This work presents the first study of the U, Th-bearing minerals (monazite, xenotime) in the SE Mediterranean margin of Spain (El Hoyazo, Almería province). Monazite has been found as tiny (10-120 $\mu \mathrm{m})$, non-zoned, rounded and elongated inclusions, which are hosted in garnet crystals and matrix from metamorphic xenoliths disseminated in the volcanics. The detailed analysis of its chemical composition indicates $\mathrm{Ce}$ and $\mathrm{Gd}$ are the most significant LREE and HREE (up to $32.5 \mathrm{wt} \% \mathrm{Ce}_{2} \mathrm{O}_{3}$ and $1 \mathrm{wt} \% \mathrm{Gd}_{2} \mathrm{O}_{3}$, respectively). All monazite inclusions display similar descendent REE distribution pattern, and a pronounced negative anomaly in $\mathrm{Yb} . \mathrm{Sm}_{2} \mathrm{O}_{3}$ vs. $\mathrm{La}_{2} \mathrm{O}_{3}$ and $\mathrm{Y}_{2} \mathrm{O}_{3}$ vs. $\sum$ HREE diagrams verify the high-grade metamorphism of the host metamorphic xenoliths. This has already been deduced by other petrological and geochemical studies and appears to confirm the parallel genetic history of this environmentally significant REE mineral and its host xenoliths.

Although the small amounts in which these monazites occur mean their influence could be considered of little importance, it should be remembered that natural mechanisms have concentrated large masses of monazite rich sands: the "Rambla de las Granatillas placer-type deposit". The Quaternary alluvial fan, that forms the placer deposit, covers an area of $1 \mathrm{~km}^{2}$ and has a maximum thickness of $40 \mathrm{~m}$. Garnets (main carriers of U, Th-monazite) are found loose in layers $5-50 \mathrm{~cm}$ thick and up to $50 \%$ in volume garnet-rich. At the beginning of the twentieth century, garnet exploitation reached an all-time high, peaking in 1933. From 1996 until very recently, a private company, Garnetkao, S. L., had recommenced the exploitation intermittently. The end product is an 80-mesh garnet-rich powder, and the average yield was estimated at 6t/day (Lunar, MartinezFrias, Benito and Wolf, 1999).

Therefore, an environmental monitoring and management plan of the area is necessary, not only for the presence of uranium and thorium but also for radium, radon, and several isotopes of polonium, lead, and bismuth which are also related to the decay of both elements. This plan should be focussed on the source volcanic outcrops and the monazite sands, on the final industrial garnetiferous product and its exportation. In this sense, it is important to note that some international regulations (e.g. Regulation 11 of The Department of Industry, Science and Resources, Australia) include severe exportation restrictions for "Nuclear source material which comprises uranium and thorium (including thorium contained in monazite obtained from mineral sands) and special fissionable material includes plutonium".

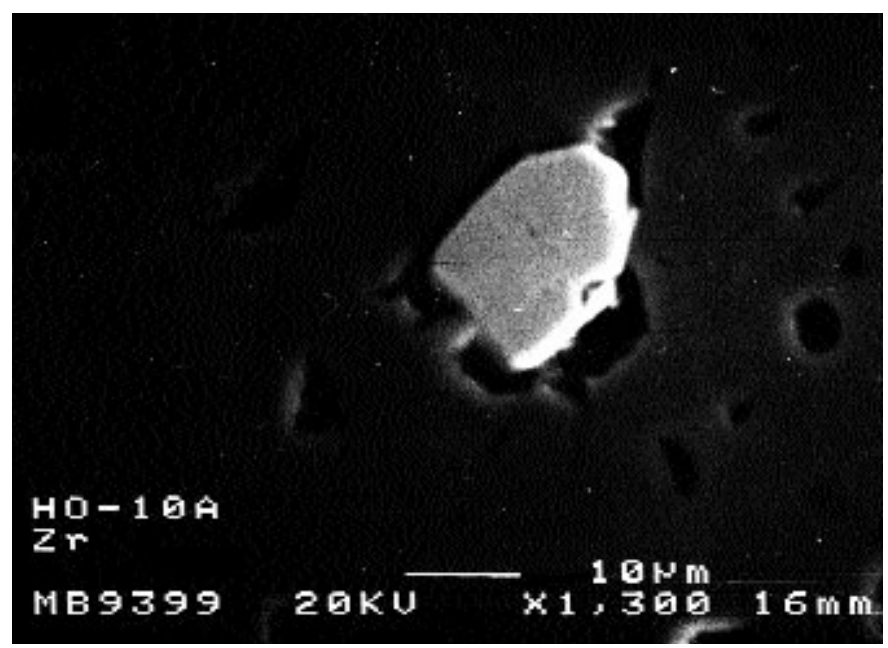

Figure 5 Sub-idiomorphic inclusion of zircon in a small cavity in a garnet grain. 


\section{Acknowledgments}

This work was carried out in cooperation with a Spanish/German NATO Collaborative Research Grant. Thanks to Matthew Harffy and Paul Giblin for the correction of the English version.

\section{References}

Australian Customs Service 2001 Manuals. Division 4. Export prohibitions and authorisation. Section 5. Department of Industry, Science and Resources. 4/5/2 Nuclear Source Material. http://www.customs.gov.au/corp/manuals/vol12/text/div4s5.htm .

Alvarez M.C.A. and Vivero, M.T.D. 1998. Natural radionuclide contents in Spanish coals of different rank. Fuel 77-13, pp.1427-1430.

Andreo, B. and Carrasco, F. 1999. Application of geochemistry and radioactivity in the hydrogeological investigation of carbonate aquifers Sierras Blanca and Mijas, southern Spain. Applied Geochemistry 14 3, pp.283299.

Bea, F., Pereira, M.D., Corretge, L.G., and Fershtater, G.B. 1994. Differentiation of strongly peraluminous, perphosphorous granites. The Pedrobernardo pluton, Central Spain. Geochimica et Cosmochimica Acta, 58-12, pp.2609-2627.

Bea, F. 1996. Controls of the trace-element composition of crustal melts. Transaction of the Institution of Mining and Metallurgy, 87, 1-2, pp.3341.

Bellon, H., Bordet, P. and Montenat, C. 1983. Chronologie du magmatisme néogène des Cordilléres Bètiques Espagne méridionale. Bull. Soc. Geol. France, 7-25, pp.205-217.

Benito, R. 1993: Hibridación del manto y asimilación de corteza continental en el magmatismo calco-alcalino pot-sico y shoshonítico del sureste de España. Tesis Doctoral in Spanish. Universidad Autónoma de Madrid, $222 \mathrm{p}$.

Benito, R., Martinez-Frias, J., Lunar, R. and Wolf, D. 1999 "The unique garnet-rich volcanic Complex of El Hoyazo SE Spain. Trans. Inst. Min. Met, 107: pp.158-165

Casillas, R., Nagy, G., Panto, G., Brandle, J. and Forizs, I. 1995. Occurrence of Th-bearing, U-bearing, Y-bearing, Zr-bearing, and REE-bearing accessory minerals in late-Variscan granitic-rocks from the Sierra de Guadarrama Spain. European Journal of Mineralogy, 7-4, pp.989-1006.

Cesare, B., Salvioli, E. and Venturelli, G. 1997. Crustal anatexis and melt extraction during deformation in the restitic xenoliths at El Joyazo SE Spain. Mineralogical Magazine, 61: pp.15-27.

Cesare, B., Gomez-Pugnaire, M.T. and Rubatto, D. 2003. Residence time of S-type anatectic magmas beneath the Neogene Volcanic Province of SE Spain: a zircon and monazite SHRIMP study. Cont. Min. Petrol. 146, 1, pp. 28-43.

Dueñas, C., Fernandez, M.C., Enriquez, C., Carretero, J., and Liger, E. 1998. Natural radioactivity levels in Andalusian spas. Water Research, 32, 8, pp.2271-2278.

Edwards, M.A. and Harrison, T.M. 1997. When did the roof collapse? Late Miocene north-south extension in the high Himalaya revealed by Th- $\mathrm{Pb}$ monazite dating of the Khula Kangri granite. Geology, 25-6, pp.543-546.

Evans, J. and Zalasiewicz, J. 1996. U-Pb, Pb-Pb and Sm-Nd dating of authigenic monazite: Implications for the diagenetic evolution of the Welsh Basin. Earth and Planetary Science Letters, 144: 3-4, pp.421-433.

Fitzsimons, I.C.W., Kinny, P.D. and Harley, S.L. 1997. Two stages of zircon and monazite growth in anatectic leucogneiss: SHRIMP constraints an the duration and intensity of Pan-African metamorphism in Prydz Bay, East Antarctica., Terra Nova, 9-1: pp.47-51.

Franz, G., Andrehs, G. and Rhede, D. 1996. Crystal-chemistry of monazite and xenotime from Saxothuringian-Moldanubian metapelites, Bavaria, Germany. European Journal of Mineralogy, 8-5, pp.1097-1118.

García-Talavera, M., Quintana, B., García-Diez, E. and Fernández, F. 2001. Studies on radioactivity in aerosols as a function of meteorological variables in Salamanca Spain. Atmospheric Environment 35, pp.221-229.

Gonzalez-Labajo, J., Bolivar, J.P., and García-Tenorio, R. 2000. Natural radioactivity in waters and sediments from a Spanish mining river. Radiat. Phys. Chem. 3-6: pp.643-644.

Herranz, M., Abelairas, A., and Legarda, F. 1999. Uranium contents in raw waters from Biscay Spain Applied Radiation and Isotopes, 51, 2, pp.203208.

Lanzirotti, A. and Hanson, G.N. 1996. Geochronology and geochemistry of multiple generations of monazite from the Wepawaug schist, Connecti- cut, USA. Implications for monazite stability in metamorphic rocks. Contributions to Mineralogy and Petrology, 125-4, pp.332-340.

Lide, D.R. 2003. Handbook of Chemistry and Physics. 84th Edition CRC Press $2664 \mathrm{p}$.

López Ruiz, J., Rodríguez Badiola, E. and García Cacho, L. 1977. Origine des grenats des roches calco-alcalines du Sud-Est de l'Espagne. Bull.Volcanologique, 40: pp.1-12.

López Ruiz, J. and Rodríguez Badiola, E. 1980. La región volcánica neógena del sureste de España. Estudios Geológicos. 36: pp.5-63.

López Ruiz, J. and Wasserman, M.D. 1991. Relación entre la hidratación/desvitrificación y el $\delta^{18} \mathrm{O}$ en las rocas volcánicas neógenas del SE de España. Estudios Geológicos. 47: pp.3-11.

Lunar, R., Martinez-Frias, J., Benito and Wolf, D. 1999. Garnets in Europe: geology and beneficiation of the only economic ore deposit of Spain Geotimes, 44-1, pp.23-28.

Maderich, V.S. 1999. Reconstruction and prediction of radionuclide transport in the Mediterranean sea chain. Journal of Environmental Radioactivity, 43, 2, pp.205-219.

Martinez-Aguirre, A. and García-Leon, M. 1997. Radioactive impact of phosphate ore processing in a wet marshland in southwestern Spain. Journal of Environmental Radioactivity, 34, 1, pp.45-57.

Martinez-Aguirre, A. and Perianez, R.. 1999. Distribution of natural radionuclides in sequentially extracted fractions of sediments from a marsh area in Southwest Spain: U isotopes. Journal of Environmental Radioactivity, $45,1, \mathrm{pp} .67-80$.

MartÌnez-Frías, J., Lunar, R., Benito, R., Wolf, D., Delgado, A. and Muñoz Espadas, M.J. 1998. The controversy over the origin of garnets from the El Hoyazo volcanic Complex: New textural, chemical and isotopic data. Terra Nova, 10, 38.

Molin, D. 1980. Le volcanisme miocène du Sud-Est de l'Espagne Provinces de Murcia et d'Almeria. Thèse 3ème cycle, Paris VI, 289 p.

Munksgaard, N.C. 1984. High $\delta^{18} \mathrm{O}$ and possible pre-eruptional Rb-Sr isochrons in cordierite-bearing Neogene volcanics from SE Spain. Contrib. Mineral. Petrol. 87, pp.351-358.

Munksgaard, N.C. 1985. A non-magmatic origin for compositionally zoned euhedral garnets in silicic Neogene volcanics from SE Spain. Neues Jb. Miner. Mh., 73-82.

Muñoz-Espadas, M.J., Lunar, R. And Martinez-Frias, J. 2000. The garnet placer deposit from SE Spain: industrial recovery and geochemical features. Episodes, 23, 4, pp 266-270.

Pelegrina, J.M.A. and Martínez-Aguirre, A. 2001. Natural radioactivity in groundwaters around a fertilizer factory complex in south of Spain. Appl. Radiat. Isotopes. 55 3, pp.419-423.

Poitrasson, F., Chenery, S. and Bland, D.J. 1996. Contrasted monazite hydrothermal alteration mechanisms and their geochemical implications. Earth and Planetary Science Letters, 145, 1-4, pp.79-96.

Pujol, L. and Sanchez-Cabeza, J.A. 2000. Natural and artificial radioactivity in surface waters of the Ebro river basin Northeast Spain. Journal of Environmental Radioactivity 51 2, pp.181-210.

Reyes, E., Del Villar, L.P., Delgado, A., Cortecci, G., Nunez, R., Pelayo, M. and Cozar, J.S. 1998. Carbonatation processes at the El Berrocal natural analogue granitic system Spain: inferences from mineralogical and stable isotope studies. Chemical Geology 150, 3-4, pp.293-315.

San Miguel, E.G., Bolívar, J.P., García-Tenorio, R. and Martín, J.E. 2001. Th-230/Th-232 activity ratios as a chronological marker complementing $\mathrm{Pb}-210$ dating in an estuarine system affected by industrial releases. Environ. Pollut.112 3, pp.361-368.

Tsai, C.S. and Yeh, S.J. 1997. Determination of rare earth elements in Taiwan monazite by chemical neutron activation analysis. Journal of Radioanalytical and Nuclear Chemistry, 216-2, pp.241-245.

US Department of Energy 1999. Naturally occurring radioactive materials and the WIPP. Carlsbad Area Office The Waste Isolation Pilot Plant 99002 - NORM 11/99. Waste Isolation Pilot Plant http://www.wipp.carlsbad.nm.us/fctshts/backrad.pdf

Zalduegui, J.F.S., Scharer, U., Ibarguchi, J.I.G., Girardeau, J. 1996. Origin and evolution of the Paleozoic Cabo-Ortegal ultramafic-mafic Complex NW Spain. U-Pb, Rb-Sr and Pb-Pb isotope data. Chemical Geology, 129, 3-4, pp.281-304.

Zeck, H.P. 1968. Anatectic origin and further petrogenesis of almandinebearing biotite-cordierite-la-bradorite-dacite with many inclusions of restite and basaltoid material, Cerro del Hoyazo, SE Spain. Ph.D. Thesis, Amsterdam Univ. $161 \mathrm{p}$.

Zeck, H. P. 1970. An Erupted Migmatite from Cerro del Hoyazo, SE Spain. Contrib. Mineral. Petrol. 26, pp.225-246.

Zeck, H. P. 1992. Restite-melt and mafic-felsic magma mixing and mingling in an S-type dacite, Cerro del Hoyazo, southeastern Spain. Trans. Royal Soc. Edinburgh: Earth Sciences. 83, pp.139-144. 
Zeck, H. P. and Whitehouse, M.J. 2002. Pre-eruptional magmatic zircon, Neogene Alboran volcanic province, SE Spain. Journal of the Geological Society 159 , pp.343-346

Zeck, H. P. and Williams, I.S. 2002. Inherited and magmatic zircon from Neogene Hoyazo cordierite dacite, SE Spain-Anatectic source rock provenance and magmatic evolution. Journal of Petrology 43 (6), pp.1089-1104.

Zhang, J. and Nozaki, Y. (1998) Behaviour of rare earth elements in seawater at the ocean margin: a study along the slopes of Sagami and Nankai Troughs near Japan. Geochimica et Cosmochemica Acta, 62, 1307-1317.

\begin{abstract}
Jesus Martinez-Frias is Senior Scientist and Head of the Planetary Geology Laboratory at the Centro de Astrobiologia (CSIC-INTA), associated to NASA Astrobiology Institute and Professor "Ad Honorem" of the "Universidad Politécnica de Madrid”. He gained his B.Sc. in Geology in 1982 and his Ph.D. in Mineral Deposits in 1986 from the Universidad Complutense de Madrid. He has been Spanish representative of the IGCP project 318 (IUGS/UNESCO) and elected member of the UN Committee of Natural Resources (ECOSOC), representing Western Europe. At present, he is involved in various research projects, and is member of the Steering Committee of the ESF IMPACT program. Also, he is Vice-Chair of the UNCSTD (2002-2004).
\end{abstract}

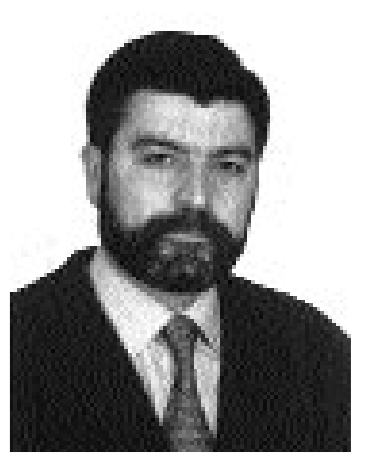

Rosario Lunar holds degrees of B.Sc in Geology (1973) and Ph.D in Economic Geology (1976) from the Universidad Complutense de Madrid. Since 1988 she has been Professor of Mineral Deposits in the Department of Crystallography and Mineralogy, Universidad Complutense. She has led the NATO Spanish-German project regarding the garnets from El Hoyazo, Nijar, Almerİa. At present, she is a member of the IGCP project 427 (IUGS/UNESCO) "Ore-Forming Processes in Dynamic Magmatic Systems".

Raul Benito gained his B.Sc. and Ph.D. in Geochemistry from the "Universidad Autónoma de Madrid". He has worked at the CIEMAT and IGME laboratories, Madrid. At present he is head of the laboratory of geochemistry at the Natural History Museum, CSIC (Madrid) and Professor of mineralogy and petrology at the Universidad Autónoma, Madrid.
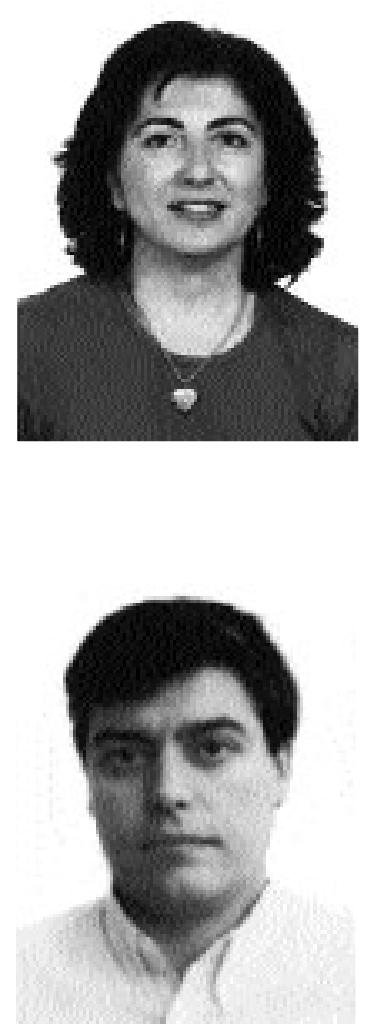

\title{
Hutchison "Young Scientist" Foundation
}

William Watt Hutchison, "Hutch" to his many friends around the world, was a Scots-born Canadian geologist who served Canada and the IUGS in myriad dynamic and creative ways. Most notably, he served as the IUGS Secretary General (1976-1980) at a pivotal time in its history, and as IUGS President (1984-1987). The same boundless energy, enthusiasm, skill in communications, and ability to foster teamwork that characterized his work with the IUGS also carried him to preeminent scientific administrative positions in the Canadian Government, where he served as Director General of the Geological Survey of Canada and as Assistant Deputy Minister of Earth Sciences. His distinguished career was terminated in 1987 by his untimely death at the age of 52, following a painful struggle with cancer.

One of Hutch's last wishes was to establish under IUGS auspices a memorial foundation intended to promote the professional growth of deserving, meritorious young scientists from around the world by supporting their participation in important IUGS-sponsored conferences. The first 3 beneficiaries of the Hutchison "Young Scientist" Foundation attended the 28th International Geological Congress (IGC) in Washington, D.C., in 1989.

Initially, earned interest on the funds available to the Hutchison Foundation were insufficient to sustain comparable grants every four years without seriously eroding the principal. For that reason, the IUGS made no grants from the Foundation for the 30th IGC (1996), preferring instead to strengthen the fund by allowing it to earn interest for a longer period of time and by appealing for donations from the international geologic community. Grants from the Foundation again supported deserving young scientists beginning with the 31st IGC (2000), and should continue for future Congresses. The IUGS would like to expand the resources of the Foundation to make it possible also to offer support to deserving young scientists to attend other important IUGS-sponsored scientific meetings. The Hutchison "Young Scientist" Foundation is a worthy cause that honors a fine, caring man and a distinguished, public-spirited scientist and administrator. The foundation also celebrates and promotes those things that gave Hutch the most professional satisfaction: geology, international scientific collaboration, and stimulating young minds.

The IUGS welcomes contributions to the Hutchison "Young Scientist" Foundation. Please send donations to:

Dr. Antonio Brambati

IUGS Treasurer

Dept. of Geological, Environmental and Marine Sci. (DiSGAM),

University of Trieste, 1-34127 Trieste, ITALY

Tel: +39040 558 2046; Fax: +39040558 2048

E-mail: brambati@univ.trieste.it

Checks in US dollars or Visa/Mastercard (please include account number and expiration date) are preferred in order to avoid the high cost of currency conversions. Residents of the U.S.A. are reminded that charitable gifts of this nature are tax deductible. 